\title{
Cage culture with tilapia induces alteration in the diet of natural fish populations: the case of Auchenipterus osteomystax
}

\author{
Strictar-Pereira, L. *, Agostinho, AA. and Gomes, LC. \\ Departamento de Biologia, Núcleo de Pesquisas em Limnologia, Ictiologia e Aquicultura - Nupélia, \\ Universidade Estadual de Maringá - UEM, Av. Colombo, 5790, CEP 87020-900, Maringá, PR, Brazil \\ *e-mail: lari.strictar@gmail.com \\ Received September 29, 2009 - Accepted April 26, 2010 - Distributed November 30, 2010
}

(With 4 figures)

\begin{abstract}
Fish rearing in cages installed in reservoirs has developed rapidly in Brazil over the last decade. However, this type of aquaculture induces some changes in the environment because of the high quantity of nutrients released into the surroundings. This study evaluated trophic changes resulting from these nutrient inputs into the diet, feeding activity and nutritional condition of Auchenipterus osteomystax, an insectivore that alternatively feeds on zooplankton. Fish were sampled with gillnets in two tilapia (Oreochromis niloticus) experimental caging aquaculture areas of the Rosana reservoir (Paranapanema River), at different distances from the cages. Samplings were carried out for 90 days (before the cages were installed and 30 and 60 days after installation). Diet analysis was based on 250 stomach contents evaluated with occurrence and volumetric methods, combined into a Feeding Index. The spatial and temporal variations in feeding activity were inferred by the stomach repletion index (stomach weight). The relative condition factor was used to evaluate the individual nutritional condition of the sampled fish. Insects and zooplankton accounted for more than $85 \%$ of the diet in any sample. Insects predominated before caging culture started and at the end of the sampling period, whereas zooplankton predominated 30 days after caging began. The repletion index increased at 30 days after caging in both areas when the condition factor was the lowest, with some recovery at the end of this period. The input of nutrients near caging areas caused a short elevation in zooplankton availability, which promoted changes in the diet of this opportunist species, increasing its feeding activity. However, these changes appeared to be unsustainable due to the poor nutritional condition of the individuals.
\end{abstract}

Keywords: eutrophication, reservoir, aquaculture, feeding, condition factor.

\section{Cultivo de tilápias em tanques rede induz alterações na dieta de comunidades naturais: o caso de Auchenipterus osteomystax}

\begin{abstract}
Resumo
O cultivo de peixes em tanques rede é uma prática crescente nos últimos anos. Entretanto, este tipo de cultivo pode causar algumas alterações no ambiente, devido à alta quantidade de nutrientes aí liberados. Assim, o objetivo deste trabalho foi avaliar as influências proporcionadas pelo cultivo de tilápias em tanques rede sobre a dieta, a atividade alimentar e a condição nutricional da surumanha Auchenipterus osteomystax, uma espécie insetívora, porém com zooplanctivoria facultativa. Os peixes foram capturados em redes de espera em duas áreas experimentais de cultivo, localizadas em dois braços do reservatório de Rosana, rio Paranapanema - Pr, a diferentes distâncias dos tanques, em intervalos de 30 dias entre as amostragens. Uma captura foi antes do início do cultivo e as demais nos dois meses subsequentes. Para a análise da dieta, foram utilizados 250 estômagos, sendo os seus conteúdos avaliados através dos métodos de ocorrência e volumétrico combinados no Índice Alimentar (IAi\%). As variações espaciais e temporais na atividade alimentar foram inferidas pelos valores médios do Índice de Repleção dos estômagos. Para a avaliação da condição nutricional da espécie, utilizaram-se as médias do fator de condição relativo. A alimentação da espécie variou entre insetos e microcrustáceos, que juntos contribuíram com mais de 85\% do Índice Alimentar, em qualquer dos meses ou locais avaliados neste estudo. Os valores do Índice de Repleção apresentaram um acentuado incremento no trigésimo dia após a instalação dos cultivos, caindo no mês subsequente, em ambas as áreas com o experimento. Quanto à condição nutricional, a surumanha apresentou os menores valores após 30 dias de cultivo, com alguma recuperação ao final do experimento, especialmente nas áreas dos tanques. As entradas de nutrientes nas áreas de criação de peixes em tanques rede podem propiciar uma elevação, mesmo que temporária, na disponibilidade de organismos planctônicos, com reflexos positivos na atividade alimentar de algumas espécies e implicações na mudança da dieta de espécies oportunistas. Entretanto, essas mudanças podem ser insustentáveis para a condição dos indivíduos.
\end{abstract}

Palavras-chave: eutrofização, reservatório, aqüicultura, alimentação, condição. 


\section{Introduction}

Brazilian fish farming is traditionally practiced in excavated tanks. But, there is a growing expansion of caging in reservoirs. This type of cultivation has been supported by government agencies due to the low implementation costs and to the hypothetical fast investment return (Agostinho et al., 2007). Fish in the cultivation systems of floating cages are fed by external inputs, meaning a constant input of nutrients (nitrogen-N and phosphorus-P), proteins and carbon (Tacon and Forster, 2003) that, depending on the scale, can result in deterioration of water quality. The more intensive the system is, the higher the density of fish and input load will be. With this high nutrient load, it is common that caging aquaculture becomes a significant waste producer due to: i) the uneaten food, which is carried by the current or sinks to the bottom; ii) constant waste production (i.e., feces, ammonia, urea), which is also carried by water currents; and iii) the residuals of biocides and biostatic medication used to prevent pathogens and proliferation of parasites (Agostinho et al., 2007). Around 26\% of the dry weight of the ration consumed by fish is excreted as feces (Pillay, 2004). Therefore, it is expected that there will be great losses of $\mathrm{N}$ and $\mathrm{P}$ for the surrounding environments.

The area for caging aquaculture is mainly selected based on the facility to enter the market and its appropriateness to production, not considering the several uses of the water (Agostinho et al., 2008). However, there is little effort in determining the impacts that may be caused to aquatic environments, such as destruction of natural habitats, eutrophication (carrying capacity), introduction of alien species or decrease in genetic variability, changes in the structure and dynamics of the biota, with possible local extinctions (Agostinho et al., 1999a; Alves e Baccarin, 2005; Schober, 2005). Among all these factors, eutrophication is the most important modification induced by humans (Pinto-Coelho et al., 2005) and there are few studies evaluating its effects on biodiversity for the neotropical region (Crossetti et al., 2008). In spite of the paucity of information on the impact that caging has on aquatic biota and the multiple uses of public waters, this type of aquaculture has been strongly supported by governmental agencies and hydropower companies. In fact, studies developed in other continents show its potential effect to harm aquatic communities (see Agostinho et al., 2007 for review).

Apart from the water quality problems, nutrient inputs promote changes in fauna present outside of cages at different scales, leading to proliferation of some species and to a reduction of those less tolerant to changes. Thus, it is possible that alterations in the community structure, either through effects on recruitment or attractiveness of caged areas to opportunist fish species, lead to changed densities, predator-prey relationships and an increased incidence of parasites and diseases (Agostinho et al., 1999b). At the population level, it is also expected that modifications in the diet and in the nutritional condition of the species will occur.
In this context, the general objective of this study was to evaluate possible effects of caging aquaculture on the population of an opportunistic and abundant species, the surumanha Auchenipterus osteomystax, an insectivore with pre-adaptations to be a planktivore. Specifically, we hypothesised that caging aquaculture will promote changes in diet (as a result of nutrient inputs) due to increased food availability, which, for instance, will enhance feeding activity and nutritional condition.

\section{Material and Methods}

\subsection{Study area}

This study was conducted along with the experimental cage production of tilapia (Oreochromis niloticus) at sites in two arms of the Rosana Reservoir (former lower stretches of the Guairacá and Corvo streams), in the low Paranapanema River - one of the main tributaries from the left margin of the Paraná River $\left(22^{\circ}\right.$ and $36^{\prime} \mathrm{S} ; 52^{\circ}$ and 52' W). This reservoir was closed in 1986 and has a shallow depth. The total draining area is 27.600 ha, and it has a water residence time of 18.6 days (CESP, 1998). The reservoir surface area is $220 \mathrm{~km}^{2}$, with a length of $116 \mathrm{~km}$ and a volume of $1920 \times 10^{6} \mathrm{~km}^{3}$ as well as an average annual flow of $1203 \mathrm{~m}^{3} \cdot \mathrm{s}^{-1}$ (Figure 1)

The Rosana Reservoir is the last in a cascade of nine reservoirs in the Paranapanema River. It presents high water transparency and alkalinity, has reduced total phosphorus and nitrogen concentrations, and has been classified as oligotrophic by Nogueira et al. (2002) and Pagioro et al. (2005a; b).

The slopes of the study area are occupied by pastures. The Corvo area receives effluents from a manioc flour industry after primary treatment. In this stream, cages were installed about $1.5 \mathrm{~km}$ from the main body of the reservoir, whereas in the Guairacá stream, cages were set close to the reservoir $(600 \mathrm{~m})$.

\subsection{Experimental design}

The experimental cultivation was composed of 12 floating cages (set transversally) in each arm of the reservoir. Each cage measured $2.0 \times 2.0 \times 1.7 \mathrm{~m}$, to which we applied three treatments $\left(150,225\right.$ and 300 fish.m $\left.{ }^{-2}\right)$. The tilapia, O. niloticus, fry were acquired from a hatchery properly regulated by the state agencies. Each individual weighed $10 \mathrm{~g}$ and had undergone sexual reversion.

To sample fish, we set batteries of gill nets (13 nets; 2.4 to $16 \mathrm{~cm}$ mesh size - opposite knots) near the cages, $100 \mathrm{~m}$ and $500 \mathrm{~m}$ upstream and downstream from them (herein named Cages, Upstream and Downstream, respectively), because, in both areas, the flow can be altered, due to effects of the reservoir. Thus, for each sampling, we installed three batteries of gill nets $500 \mathrm{~m}$ downstream; three batteries $100 \mathrm{~m}$ downstream; three batteries near the cages; three batteries $100 \mathrm{~m}$ upstream; and three batteries 500 upstream (replicates), totalling 15 batteries per sample. Sampling was conducted before installing the cages (April 2006) and at 30-day intervals in the two subsequent months (May and 


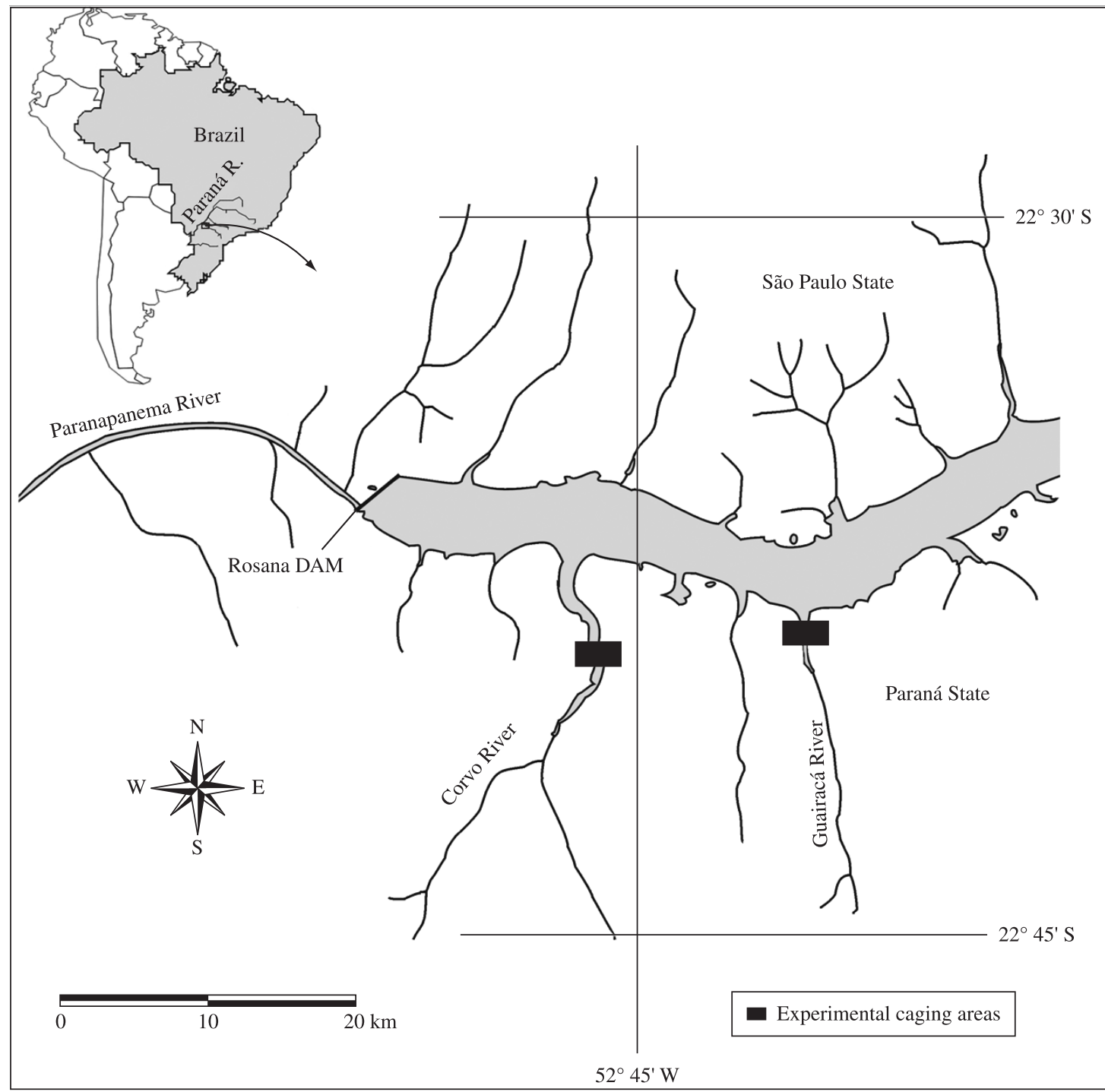

Figure 1. Map of the Rosana Reservoir showing the two arms where the study was conducted.

July 2006) and checked three times throughout the day that they were set (10:00 PM, 8:00 AM and 4:00 PM). Due to logistic limitations, we were not able to have a control. Thus, we opted to sample before caging aquaculture started, which served as a starting point for the variables we wanted to evaluate.

\subsection{Diet}

We recorded for each individual captured the total and standard length, sex and the degree of stomach fullness. Stomachs were removed, weighed and fixed in formalin for posterior analysis. Diet was determined through the analysis of 250 stomachs of Auchenipterus osteomystax (Miranda-Ribeiro, 1918) conducted under stereo and optical microscopes. All food items were identified to the least taxonomic level possible. The feeding index
(IAi\%) (Kawakami and Vazzoler, 1980) was calculated to characterise the diet, which combines the total volume (\%) and the frequency of occurrence (\%) of each item (Hyslop, 1980) (Equation 1):

$$
\mathrm{IAi} \%=\frac{\mathrm{Fi} * \mathrm{Vi}}{\sum_{\mathrm{i}=1}^{\mathrm{L}} \mathrm{Fi} * \mathrm{Vi}}
$$

where: $\mathrm{Fi}$ is the frequency of occurrence of item $\mathrm{i}(\%)$; $\mathrm{Vi}$ is the relative volume of item $\mathrm{i}(\%)$; and $\mathrm{L}$ is the number of items.

The volume (V) of each item was obtained in two ways: i) by measuring the displacement of the water column in graduated cylinders, when the volume was higher than $0.1 \mathrm{~mL}$; or ii) by using a millimetre plate, 
where the volume was given in $\mathrm{mm}^{3}$ and later transformed into millilitres, when the volume was lower than $0.1 \mathrm{ml}$ (Hellawel and Abel, 1971).

\subsection{Data analysis}

To evaluate possible differences in diet, we opted for an ordination technique (Detrended Correspondence Analysis - DCA; Gauch Jr. 1982), applied on the diet matrix (items in the columns and individuals in the rows, controlling for sites and months) of each arm separated; using PCord (McCune and Mefford, 1997). The items with only one occurrence were excluded from the analysis, considering that they usually influence ordinations (Palmer, 1993). Axes with eigenvalues greater than 0.20 (Matthews, 1998) were retained for interpretation. The food items that most influenced the DCA (positively or negatively) were determined using the correlation with the main matrix (available in PCord) that gives a Pearson correlation between the scores of a given axis and the original data matrix.

Scores of the axes retained were generated and tested to evaluate differences in the spatial (factor sites, with levels cages, upstream and downstream - $100 \mathrm{~m}$ and $500 \mathrm{~m}$ pooled) and temporal (factor months, with three levels; April - before; May - 30 days after the beginning; July 60 days after the beginning). To test differences between mean scores for the factors sites and months (as well their interaction), we used two-way analyses of variance (ANOVA). As several ANOVAs were conducted (one for each retained axes), we applied the protected ANOVA protocol to reduce the probability of Type I error (Scheiner and Gurevitch, 1993). In this protocol, first a multivariate analysis of variance (MANOVA) is applied, and if it is significant, there are differences that are not at random, and ANOVAs for each axis can be applied. These analyses were performed with the software STATISTICA ${ }^{\text {TM }}$ 7.0.

Spatial and temporal variations in feeding activity, of 1079 individuals, were determined using averages of the repletion index, estimated for each individual through the relative contribution of the stomach weight (We) in the total weight (Wt) (Equation 2):

$$
\mathrm{IR}=\mathrm{We} / \mathrm{Wt} * 100
$$

Spatial (among sites) and temporal (months) variations in average IR were evaluated by two-way ANOVA (sites and months and their interaction were the factors), using the software STATISTICA ${ }^{\mathrm{TM}}$ 7.0.

Variations in the nutritional condition of the surumanha A. osteomystax in the samples were evaluated by the relative condition (K; Le Cren, 1951), calculated for each 1079 individual by the Equation 3:

\section{$\mathrm{K}=\mathrm{W} / \mathrm{W}^{\prime}$}

where: $\mathrm{W}$ is the individual real weight $(\mathrm{Wt}, \mathrm{g})$; and $\mathrm{W}$ ' is the estimated weight through the total length $(\mathrm{Lt}, \mathrm{cm})$ and weight $(\mathrm{Wt})$ relationship.

The parameters of the Lt $\times$ Wt relationship were obtained for each sex, considering all individuals captured. Differences between sexes were tested using analysis of covariance (ANCOVA). Then, spatial and temporal variations in average $\mathrm{K}$ were evaluated by two-way ANOVA (months and sites and their interactions were the factors), using the software STATISTICA ${ }^{\mathrm{TM}}$ 7.0.

We opted for the repletion index because it represents the amount of food taken by a fish in a short temporal scale whereas the condition factor represents the well being of an individual in a longer temporal scale when compared to the repletion index.

\subsection{Results}

\subsubsection{Diet}

The Auchenipterus osteomystax diet was, in general, composed of insects and microcrustaceans, contributing to more than $85 \%$ of the feeding index, in any studied month and at any site (Table 1) in the two arms. Among the microcrustaceans, Cladocera (Diaphanosoma, Ceriodaphnia, Moina, Daphnia, Alona, Bosmina, Macrothrix) presented high values of IAi\% in June, especially Upstream for the Guairacá. However, Copepoda (Notodiaptomus, Thermocyclops, Mesocyclops and Argyrodiaptomus) presented high values in May, in the Guairacá and Corvo arms. Predominant insects were Coleoptera (in April for Upstream and Cage) and Lepidoptera (April, especially in Upstream and Downstream) in the Guairacá area and Diptera (immature stages of Chaoboridae, Chironomidae and Ceratopogonidae; April and June in all sites) in the Corvo area.

The DCA applied to the diet matrix of the Guiaracá arm presented three axes with eigenvalues greater than 0.20 and were retained for interpretation. For the Corvo arm, the DCA presented only two axes with eigenvalues greater than 0.20 . Sample scores of these axes were retained for further analysis, conducted separated of each arm.

The MANOVA applied to the scores of the DCA axes retained for interpretation, for the Guairacá arm, revealed significant differences for the factors months and sites (MANOVA; F > 2.66; $\mathrm{p}<0.002$ ), indicating that variations were not at random, allowing the application of ANOVAs for the scores of each DCA axis separated. Similar results were obtained for the Corvo area, with non-significant values for sites (MANOVA; F > 0.56; $\mathrm{p}<0.76$ ).

In the Guairaca area, the ANOVA applied to the first DCA axis (eigenvalue $=0.82$; Figure $2 \mathrm{a}$ ) showed that the diet varied significantly among months, according to the sites (significant interaction; ANOVA; $\mathrm{F}_{4 ; 90}=4.34$, $\mathrm{p}<0.003)$. The main items that positively influenced this axis were Lepidoptera $(r=0.398)$, which were most consumed surrounding the cages and upstream, especially before the experiment (April 2006), and Coleoptera ( $\mathrm{r}=$ 0.342 ), which became more important before and at the end of the experiment, especially upstream. Copepods were negatively related $(\mathrm{r}=-0.657)$ and composed more than $92 \%$ of the diet in May, 30 days after cultivation began (Table 1).

Scores of the second DCA axis, in this locality (eigenvalue $=0.52$; Figure $2 b$ ) varied significantly among 


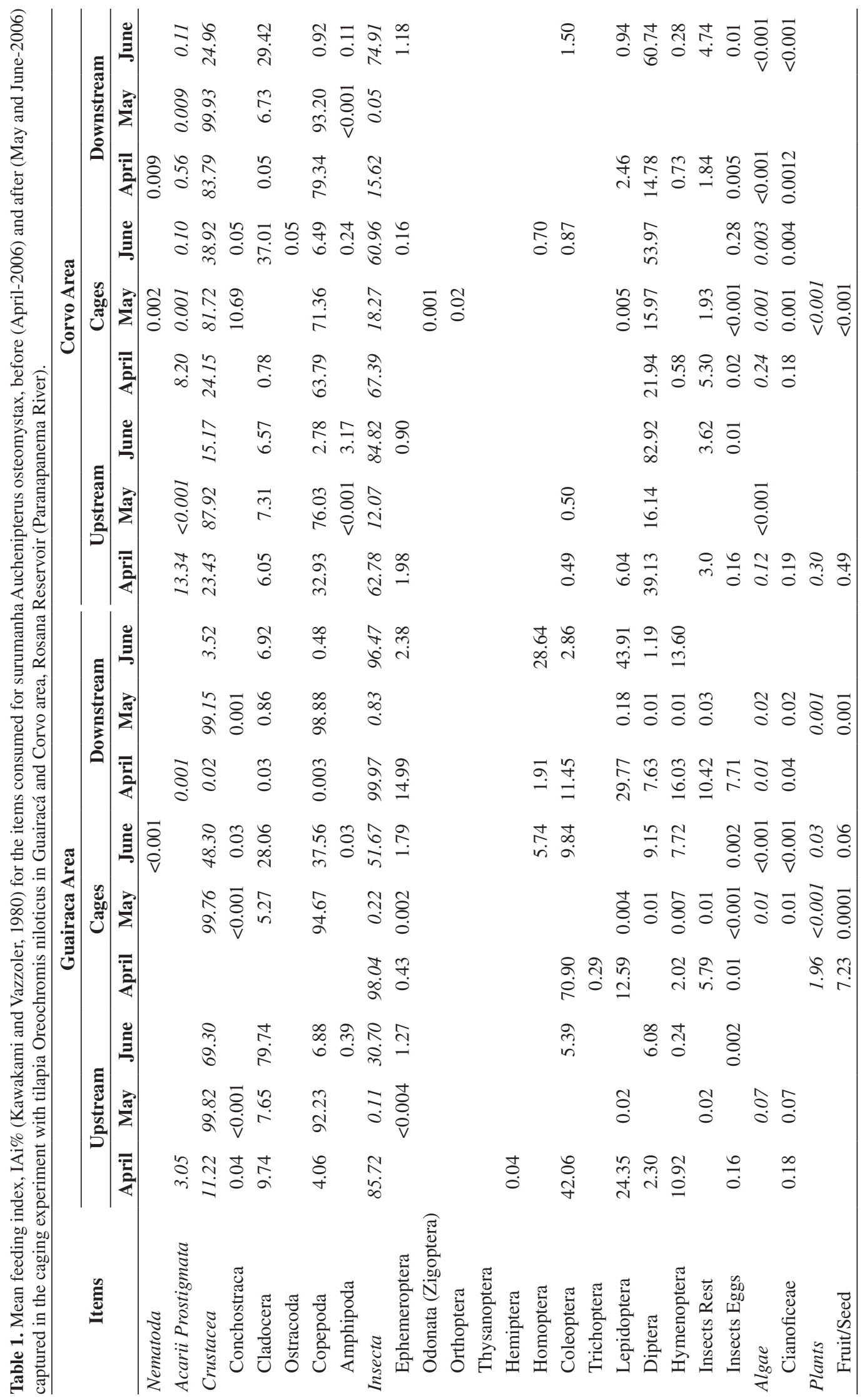


months $\left(\mathrm{F}_{2 ; 90}=5.64, \mathrm{p}<0.005\right)$ and sampling sites $\left(\mathrm{F}_{2 ; 90}=\right.$ $4.38, \mathrm{p}<0.02$; interaction was not significant). Coleoptera $(\mathrm{r}=-0.465)$ and Cladocera $(\mathrm{r}=0.226)$ influenced the trends negatively and positively, respectively, being the first most abundant before caging and the second most abundant at the end of the study period respectively. Both Coleoptera and Cladocera presented secondary relevance in the individual diet samples downstream of the cultivation area.

The third axis (eigenvalue $=0.36$; Figure $2 \mathrm{c}$ ) presented significant interaction between months and sites $\left(\mathrm{F}_{2 ; 90}=3.208\right.$, $\mathrm{p}<0.02$ ), indicating that the diet was different in months according to the sites. This axis was more positively influenced by eggs $(r=0.303)$ and negatively by non- identified insects (fragments) $(r=-0.249)$, which were frequent in the fish diets downstream of the experimental area before the installation of the cages.

In the Corvo area, the scores of the first DCA axis (eigenvalue $=0.46$; Figure $2 \mathrm{~d}$ ) indicated significant variations in the surumanha diet among months, according to the site (significant interaction; ANOVA; $\mathrm{F}_{4: 83}=3.26$, $\mathrm{p}<0.016$ ). These variations were influenced by the dominance of Copepoda in the diet $(\mathrm{r}=-0.646)$ one month after cage installation and by Lepidoptera $(r=0.423)$ only in April, both up- and downstream from the caging area. The second DCA axis (eigenvalue $=0.29$, Figure 2e), also with significant interaction among sites and months
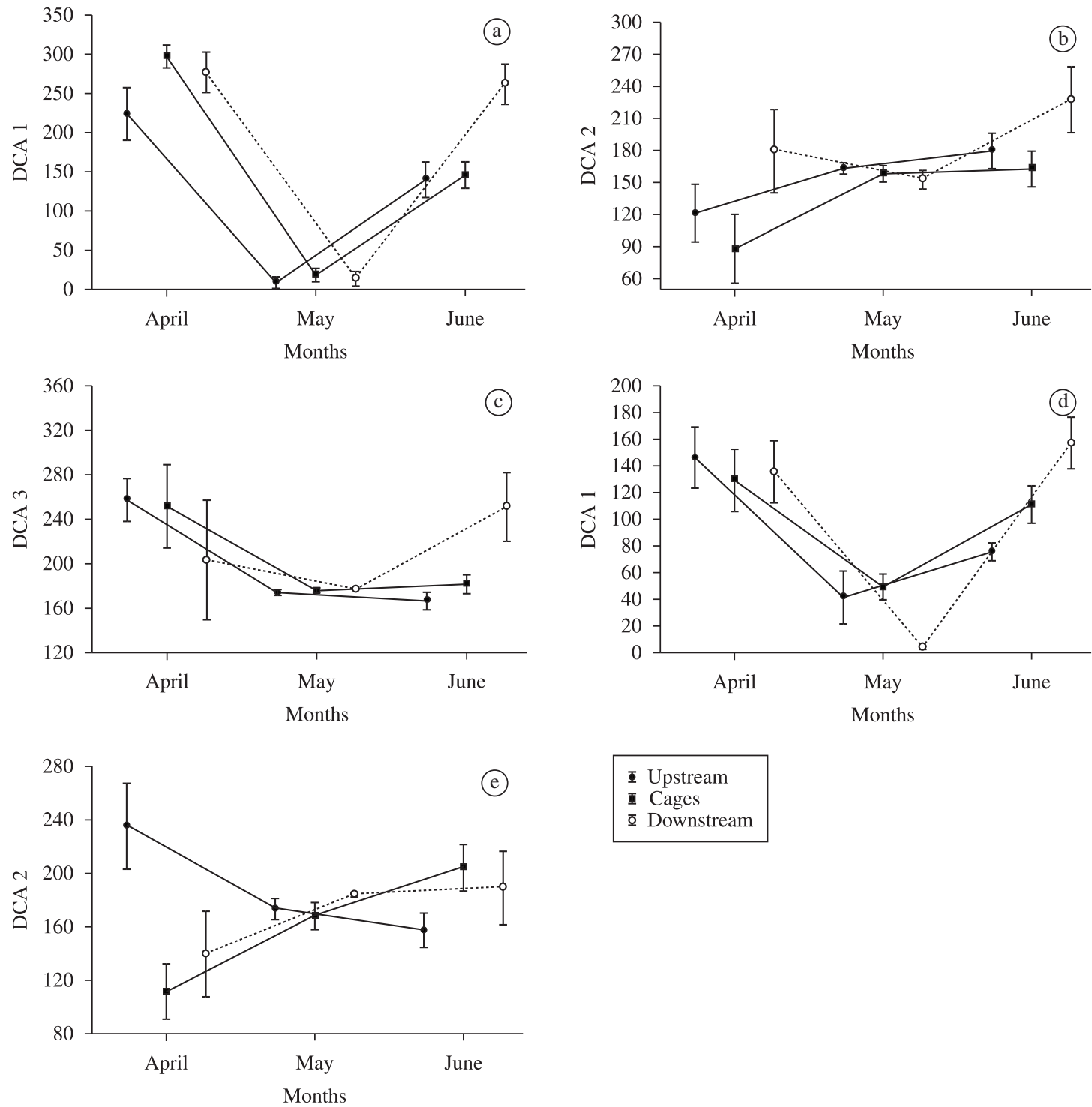

Figure 2. Variations in the average scores of the detrended correspondence analysis (DCA) axis retained for interpretation, considering months (April = before caging; May: 30 days after the beginning; June: 60 days after) and sites (Downstream and upstream from the caging area and near the cages). Vertical bars = standard error. Panels a), b) and c) refers to Guairacá whereas d) and e) to Corvo. 
(ANOVA; $\mathrm{F}_{4 ; 83}=3.26, \mathrm{p}<0.016$ ), was affected mainly by the variations in Cladocera in the diet $(r=0.34)$, which became important after the fish farm started, especially at the end of the study period.

\subsection{Variations in feeding activity}

The ANOVA applied to the values of the stomach repletion index (IR) did not reveal significant differences among sites for both of the experimental caging areas (the Guairacá and Corvo arms). However, significant differences (ANOVA; F > 100.0; $\mathrm{p}<0.001$ ) among months were found in both areas, but with interactions between months and sites that were significant in the Corvo arm (ANOVA; $\mathrm{F}_{4 ; 469}=2.41 ; \mathrm{p}=0.048$ ). The mean values of the IR presented high increase 30 days after caging began and then decreased in the next month, in both experimental areas (Figure 3).

\subsection{Variations in the condition index}

There were significant differences between sexes (ANCOVA; $\mathrm{F}=15165.69 ; \mathrm{p}<0.001$ ) for the $\mathrm{Lt} \times \mathrm{Wt}$ relationship. Thus, estimated weights were obtained using the Equations 4 and 5 for separated sexes, according to the following:

$$
\begin{aligned}
& \text { Male: } \mathrm{Wt}=0.008643 * \mathrm{Lt}^{2.9155} \\
& \text { Female: } \mathrm{Wt}=0.005242 * \mathrm{Lt}^{3.0990}
\end{aligned}
$$

The ANOVA applied to the mean condition values $(\mathrm{K})$ did not show significant variations among sites in both of the experimental areas (the Guairacá and Corvo arms). However, significant differences were found among months for both areas $(\mathrm{F}>42.0 ; \mathrm{p}<0.0001)$, with significant interaction between months and sites in the Corvo area $(\mathrm{F}=2.61 ; \mathrm{p}=0.03)$. In the Guairacá arm, the mean relative condition factor decreased significantly after caging began (Figure 4a). Overall, the same trend was observed for the Corvo area, but with variations in the sites according to the months (Figure $4 b$ ).

\subsection{Discussion}

Surumanha is considered a dominating species in several South American reservoirs (Ferreira, 1984; Agostinho and Zalewski, 1995; Benedito-Cecilio and Agostinho, 2000; Mol et al., 2007), and its diet is composed essentially of insects, with the occasional consumption of zooplankton, as described in the literature (Hahn et al., 1998; NettoFerreira et al., 2007; Merona et al., 2001). Before the Tucuruí reservoir construction, this species' diet was diversified, but composed essentially of insects. After the dam closure, the proportion of planktonic organisms in the diet has increased from 5.8 to $25 \%$ in the reservoir area and was absent in upstream areas (Merona et al., 2001).

Analysis of the A. osteomystax stomachs shows that this species does not feed directly on the rations lost during the caged net feedings, in opposition to other opportunistic species existing in the region (i.e., Pimelodus maculatus). Food losses are reported to be responsible for high fish concentrations in areas where this modality of aquaculture is practiced (Dempster et al., 2004; Agostinho et al., 2007).

Similar patterns in the dietary variation in samples obtained surrounding the cages and at $100 \mathrm{~m}$ and $500 \mathrm{~m}$ away (up- and downstream) can be related to the mobility of the studied species, which is able to feed in one place and be captured in another. The fact that the available ration is not consumed by this species may positively affect this mobility. However, significant interaction between months and locales in relation to the variation in diet composition was found. This can be related to the longitudinal gradients on the resource availability due to effluent launch (upstream) from the manioc flour industry in the Corvo area and clear water from the reservoir main body (downstream) closer in the Guairaca area.

The differences in diet among the three months in both of the cultivation areas, especially those characterised by the elevation in the importance of microcrustaceans one month after beginning the experiment, can be explained by the significant increase in their availability (Dias, 2008). In fact, Dias' studies, conducted concurrently, revealed peaks of zooplankton density in Guairaca, 15 days after the beginning of cage raising, with no significant decrease on the thirtieth day. This tendency toward abundance was more conspicuous between copepods, the main item in the surumanha diet after 30 days of raising activity. The availability may also explain the later increase of cladocerans in its diet two months after the caging began. However the continuous samples of zooplankton showed decreases in zooplankton density, except for Rotifera (Dias, 2008).

The surumanha feeding activity (inferred by the repletion index) also had significant variation, following the density of the copepod peak, although with some local influence in the Corvo sampling. These facts attest to the availability of zooplankton and indicate that the surumanha has the efficiency to consume this kind of food. In fact, A. osteomystax has been successful in colonising reservoirs, which has been related to its ability to consume zooplankton that has been generally abundant during the first years of the reservoir formation (Ferreira, 1984; Agostinho et al., 1994). In some cases, the success of A. osteomystax has been associated with its reproductive strategy (Agostinho et al., 1999b). After the upsurging period, when high nutrient concentration promotes plankton density explosions, this fish density tends to go down (Agostinho et al., 1999b). Hahn et al. (1998) found that the long term abundance of A. osteomystax in the Itaipu Reservoir was more related to insects, especially Ephemeroptera, than to the zooplankton availability. Zooplankton was important in the diet only in the first years of this reservoir. This fact, combined with the essentially insectivorous diet of the surumanha prior to fish farming in the present study, indicates the importance of insects in its diet, and that feeding on zooplankton occurs only in an opportunistic way.

The nutritional condition, obtained through the condition factor (Le Cren, 1951), revealed that, although higher feeding activity was exhibited (higher repletion stomach medians), the surumanha presented lower relative weight 

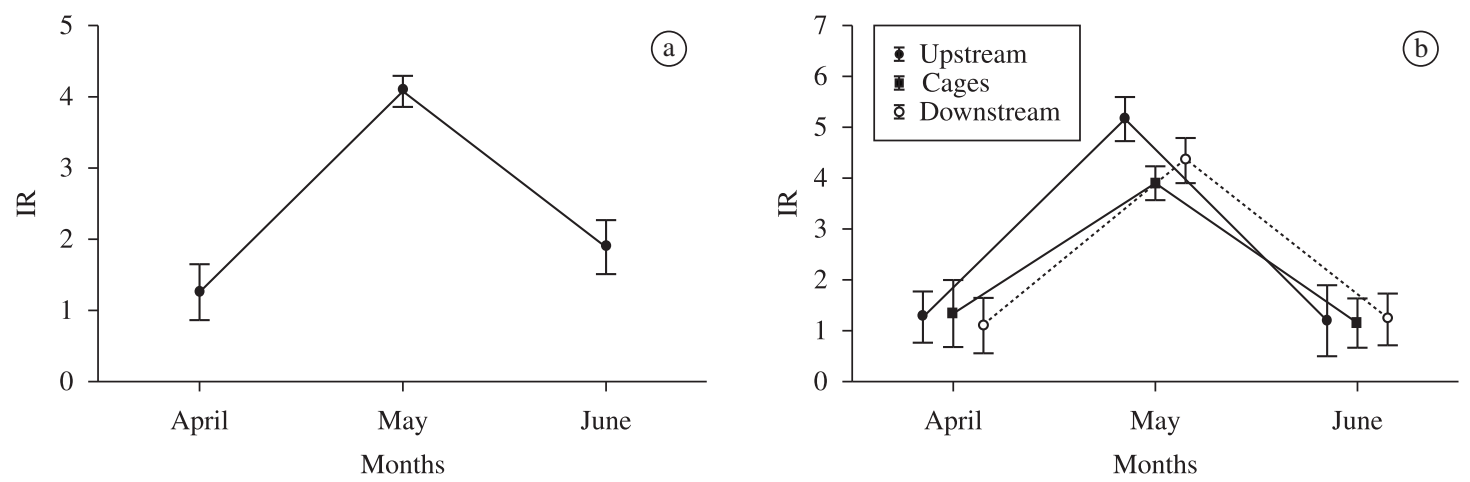

Figure 3. Average repletion index (IR) a) between months (April = before caging; May: 30 days after the beginning; June: 60 days after) in Guairacá and b) between months and sites (Downstream and upstream from the caging area and near the cages) in Corvo. Vertical bars $=$ standard error.
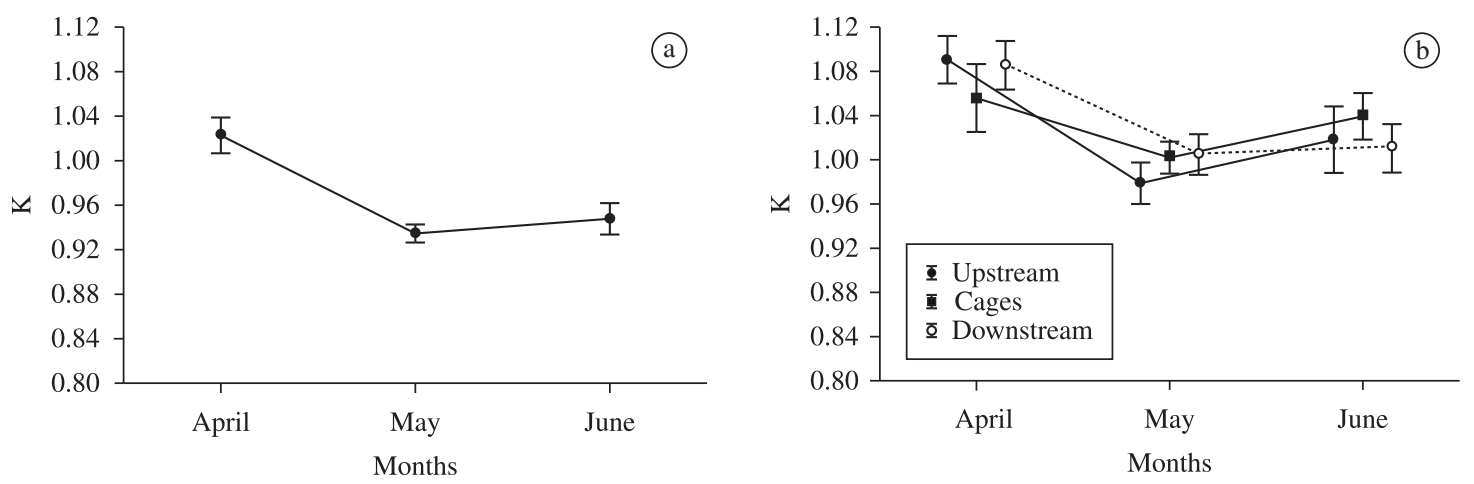

Figure 4. Variations in mean relative condition factor $(\mathrm{K})$ a) between months (April = before caging; May: 30 days after the beginning; June: 60 days after) in Guairacá and b) between months and sites (Downstream and upstream from the caging area and near the cages) in Corvo. Vertical bars $=$ standard error.

in May (when the diet was based on microcrustaceans, especially copepods). Even though the energy content of the different kinds of insects and microcrustaceans was not investigated, these results suggest that insects must be superior in relation to microcrustaceans; otherwise, the costs involved in the detection, capture, manipulation, digestion and assimilation of microcrustaceans, especially copepods, could be higher. Golley (1961) evaluated the energetic content of different animal groups and obtained a measure of 4419 g.cal.g ${ }^{-1}$ dry weight for Daphnia and 5363 g.cal.g ${ }^{-1}$ dry weight for an insect species. Given this, the tendency of a superior energy balance between microcrustaceans and insects becomes more explicit when, in addition to the drop in nutritional condition with insectivorous to planktivorous changes (April-May), a slight recovery in condition was observed when insects became more relevant in the diet at the end of the study. Although this positive balance is evident in the present study, the factors that contribute to it are unknown. It is probable, in addition to the differences in the energy content, that size, visibility and the ability of prey to flee can be considered important components in the optimal foraging theory (Gerking, 1994).

In conclusion, obtained results showed that the input of organic material, nutrients and metabolites in areas of caging aquaculture promotes, even temporarily, changes in the diet of fish towards the new resource available, with some positive consequences on the feeding activity of certain species, especially the opportunists. However, even without considering implications in community levels, the changes described may be unsustainable for organism conditions which are strongly related to their fitness.

\section{References}

AGOSTINHO, AA. and ZALEWSKI, M., 1995. The dependence of fish community structure and dynamics on floodplain and riparian ecotone zone in Paraná River, Brazil. Hydrobiologia, vol. 303, p. 141-148.

AGOSTINHO, AA., GOMES, LC. and PELICICE, FM., 2007. Ecologia e manejo de recursos pesqueiros em reservatórios do Brasil. Maringá: EDUEM. 
AGOSTINHO, AA., GOMES, LC., SUZUKI, HI. and JÚLIO Jr., HF., 1999a. Riscos da implantação de cultivos de espécies exóticas em tanques-redes em reservatórios do Rio Iguaçu. Caderno de Biodiodiversidade, vol. 2, no. 2, p. 1-9.

AGOSTINHO, AA., MIRANDA, LE., BINI, LM., GOMES, LC., THOMAZ, SM. and SUZUKI, HI., 1999b. Patterns of colonization in neotropical reservoirs, and prognoses on aging. In TUNDISI, JG. and STRASKRABA, M. (Eds.). Theoretical reservoir ecology and its applications. São Carlos, SP. p. 227-265.

AGOSTINHO, AA., HAHN, NS., GOMES, LC. and BINI, LM., 1997. Estrutura trófica. In VAZOLLER, AAM., AGOSTINHO, AA. and HAHN, NS. (Eds.). Planície de inundação do alto rio Paraná: aspectos físicos, biológicos e socioeconômicos. Maringá: EDUEM. p. 229-248.

AGOSTINHO, AA., JÚLIO, JR. and PETRERE-JUNIOR, M., 1994. Itaipu reservoir (Brazil): impacts of the impoundment on the fish fauna and fisheries. In: COWX, IG. Rehabilitation of Freshwater Fisheries. Oxford, UK. p. 171-184.

AGOSTINHO, AA., PELICICE, FM. and GOMES, LC., 2008. Dams and the fish fauna of the Neotropical region: impacts and management related to diversity and fisheries. Brailian Journal of Biology, vol. 68, no. 4, p. 1119-1132.

ALVES, RCP. and BACCARIN, AE., 2005. Efeito da produção de peixes em tanques-rede sobre sedimentação de material em suspensão e de nutrientes no córrego da Arribada (UHE Nova Avanhandava, baixo rio Tietê, SP). In NOGUEIRA, MG., HENRY, R. and JORCIN, A. Ecologia de reservatórios: impactos potenciais, ações de manejo e sistemas em cascata. São Carlos. cap. 14 , p. 329-347.

BENEDITO-CECÍLIO, E. and AGOSTINHO, AA., 2000. Distribution, abundance and use of different environments by dominant ichthyofauna in the influence area of the Itaipu Reservoir. Acta Scientiarum, vol. 22, no. 2, p. 429-437.

BEVERIDGE, M., 1987. Cage aquaculture aspects, ecology and conservation. Leiden, The Netherlands: Backhuys Publishers, p. 247-269.

Companhia Energética de São Paulo - CESP, 1998. Conservação e manejo nos reservatórios: limnologia, ictiologia e pesca. São Paulo. Série Divulgação e Informação, 220.

CROSSETTI, LO., BICUDO, DC., BICUDO, CEM. and BINI, LM., 2008. Phytoplankton biodiversity changes in a shallow tropical reservoir during the hypertrophication process. Brazilian Journal of Biology, vol. 68, suppl. 4, p. 1061-1067.

DEMPSTER, TD., SANCHEZ-PERES, P., BAYLE-SEMPERE, J. and KINGSFORD, M., 2004. Extensive aggregations of wild fish at coastal sea cage fish farm. Hydrobiologia, vol. 525, no. $1-3$, p. 245-248.

DIAS, JD., 2008. Impacto da piscicultura em tanques-rede sobre a estrutura da comunidade zooplanctônica em um reservatório subtropical, Brasil. Maringá: Universidade Estadual de Maringá. [Dissertação de mestrado].

FERREIRA, EJ., 1984. A ictiofauna da represa hidrelétrica de Curuá-Uma, Santarém, Pará. II. Alimentação e hábitos alimentares das principais espécies. Amazoniana, vol. 9, p. 1-16.

GAUCH Jr, HG., 1982. Multivariate Analysis in Community Structure. Cambridge: Cambridge University Press.
GERKING, SD., 1994. Feeding Ecology of Fish. New York: Academic Press.

GOLLEY, FB., 1961. Energy Values of Ecological Materials In WIEGERT, RG. Ecological Energetics Benchmark Papers in Ecology. Straudsburg, Pensilvania: Dowden, Hutching \& Ross, Inc, vol. 4.

HAHN, NS., AGOSTINHO, AA., GOMES, LC. and BINI, LM., 1998. Estrutura trófica da ictiofauna do reservatório de Itaipu (Paraná-Brasil) nos primeiros anos de sua formação. Interciência, vol. 23 , no. 5 , p. 299-305.

HELLAWELL, LM. and ABEL, R., 1971. A rapid volumetric method for the analysis of the food of fishes. Journal of Fish Biology, vol. 48, p. 29-37.

HYSLOP, EJ., 1980. Stomach contents analysis, a review of methods and their application. Journal of Fish Biology, vol. 17, p. 411-429.

KAWAKAMI, E. and VAZZOLLER, G., 1980. Método gráfico e estimativa de índice alimentar aplicado no estudo de alimentação de peixes. Boletim do Instituto Oceanográfico, vol. 29, no. 2, p. 205-207.

LE CREN, ED., 1951. The lenght-weight relationship and seasonal cycle in gonad and conditions in the perch Perca fluviatilis. Journal Animal Ecology, vol. 20, no. 2, p. 201.

MATTTHEWS, WJ., 1998. Patterns in freshwater fish ecology. New York: Chapman \& Hall. 756 p.

McCUNE, B. and MEFFORD, MJ., 1997. PC-ORD. Multivariate analysis of ecological data. Version 3.0. Gleneden Beach: MjM Software Design.

MÉRONA, D., SANTOS, GM. and ALMEIDA, RG., 2001. Short term effects of Tucuruí Dam (Amazônia, Brazil) on the trophic organization of fish communities. Environmental Biology of Fishes, vol. 60, no. 4, p. 375-392.

MOL, JH., MERONA, B., OUBOTER, PE. and SHAMITA, S., 2007. The fish fauna of Brokopondo Reservoir, Suriname, during 40 years of impoundment. Neotropical Ichthyology, vol. 5, no. 3, p. 351-368.

NETTO-FERREIRA, AL., ALBRECHT, MP., NESSIMIAN, JL. and CARAMASCHI, EP., 2007. Feeding habits of Thoracocharax stellatus (Characiformes: Gasteropelecidae) in the upper rio Tocantins, Brazil. Neotropical Ichthyology, vol. 5, no. 1, p. 69-74.

NOGUEIRA, MG., JORCIN, A., VIANNA, NC. and BRITTO, YCT., 2002. Uma avaliação dos processos de eutrofização nos reservatórios em cascata do rio Paranapanema (SP/PR), Brasil. In CIRELLI, AF. and MARQUISÁ, GC. El Água en Iberoamérica. De la Limnologia a la Gestión en Sudamérica. Santiago do Chile: CYTED XVII/CETA, p. 91-106.

PAGIORO, TA., THOMAZ, SM. and ROBERTO, MC., 2005a. Caracterização limnológica abiótica dos reservatórios. In. ROGRIGUES, L., THOMAZ, SM., AGOSTINHO, AA. and GOMES, LC. Biocenoses em reservatórios: padrões espaciais e temporais. São Carlos, cap. 2, p. 17-37.

PAGIORO, TA., ROBERTO, MC., THOMAZ, SM., PIERINI, SA. and TAKA, M., 2005b. Zonação longitudinal das variáveis limnológicas abióticas em reservatórios. In: RODRIGUES, L., THOMAZ, SM., AGOSTINHO, AA and GOMES, LC. 
Biocenose em reservatório: padrões espaciais e temporais. São Carlos, p. 39-46.

PALMER, MW., 1993. Putting things in even better order: the advantages of canonical correspondence analysis. Ecology, vol. 74 , p. 2215-2230.

PILLAY, TVR., 2004. Aquaculture and the environment. $2^{\text {nd }} \mathrm{ed}$. Hong Kong: Blackwell Publishing.

PINTO-COELHO, RM., BEZERRA-NETO, JF. and MORAISJr, CA., 2005. Effects of eutrophication on size and biomass of crustacean zooplankton in a tropical reservoir. Brazilian Journal of Biology., vol. 65, no. 2, p. 325-338.
SCHEINER, SM. and GUREVITCH, J., ed., 1993. Design and analysis of ecological experiments. New York: Chapman Hall.

SCHOBER, J., 2005. Aquicultura: desafios para fazer peixes para os rios sem peixes. ComCiência: revista eletrônica de jornalismo científico, n. 62. Available in: $\langle\mathrm{http} / /$ :www.comciencia. br/reportagens/2005/02/14_impr.shtml>. Access in: 20 Oct. 2008.

TACON, AGJ. and FORSTER, IP., 2003. Aquafeeds and the environment: policy implications. Aquaculture, no. 226, p. 181-189. 